\section{Storage Media For Avulsed Teeth: A Literature Review}

Wilson Roberto Poi, Celso Koogi Sonoda, Christine Men Martins, Moriel Evangelista Melo, Eduardo Pizza Pellizzer, Marcos Rogério de Mendonça, Sônia Regina Panzarini

Dental avulsion is the most severe type of traumatic tooth injuries because it causes damage to several structures and results in the complete displacement of the tooth from its socket in the alveolar bone. The ideal situation is to replant an exarticulated tooth immediately after avulsion because the extraoral time is a determinant factor for treatment success and for a good prognosis. However, it is not always possible. The success of replantation depends on a number of factors that may contribute to accelerate or minimize the occurrence of root resorption or ankylosis, among which is the type and characteristics of the medium used for temporary storage during the time elapsed between avulsion and replantation. Maintaining the tooth in an adequate wet medium that can preserve, as longer as possible, the vitality of the periodontal ligament cells that remain on root surface is the key to success of replantation. Recent research has led to the development of storage media that produce conditions that closely resemble the original socket environment, with adequate osmolality (cell pressure), $\mathrm{pH}$, nutritional metabolites and glucose, and thus create the best possible conditions for storage. Although these storage media can now be purchased in the form of retail products, the most common scenario is that such a product will not be readily available at the moment of the accident This paper reviews the literature on the different storage media that have been investigated for avulsed teeth based on full-length papers retrieved from PubMed/Medline, Lilacs, BBO and SciELO electronic databases using the key words 'storage medium', 'transportation medium', 'avulsion', 'tooth avulsion', 'replantation', 'tooth replantation', 'milk' and 'propolis'. After application of inclusion and exclusion criteria, 39 papers were selected and critically reviewed with respect to the characteristics, efficacy and ease of access of the storage medium. The review of the literature showed that a wide array of types of wet storage media have been evaluated in laboratory studies and clinical reports, including cell and tissue culture solutions like Hank's Balanced Salt Solution (HBSS); medical/hospital products developed specifically for organ storage purposes, such as Viaspan ${ }^{\circledR}$ and Euro-Collins ${ }^{\circledR}$; culture media, like Minimum Essential Medium (MEM); saline; natural products like water, saliva, bovine milk and its variations, propolis, green tea, Morus rubra (red mulberry), egg white and coconut water; rehydrating solutions, like Gatorade ${ }^{\circledR}$ and Ricetral, and even contact lens solutions. Based on the literature, it could be stated that, so far, apart from Based on the literature, it could be stated that, so far, apart from solutions designed specifically for storage and culture purposes, regular pasteurized whole milk is the most frequently recommended and with the best prognosis among other solutions that are likely to be available at the scene of an accident, such as water, saline or saliva. Its advantages include its high availability, ready accessibility, physiologically compatible $\mathrm{pH}$ and osmolality (fluid pressure) with the root-surface adhered PDL cells, presence of nutrients and growth factors. However, there is not yet a single solution that fulfills all requirements to be considered as the ideal medium for temporary storage of avulsed teeth, and research on this field should carry on.
Departament of Surgery and Integrated Clinics, Araçatuba School of Dentistry, UNESP - Univ Estadual Paulista, Araçatuba, SP, Brazil

Correspondence: Prof. Dr. Wilson Roberto Poi, Rua José Bonifácio 1193, CEP: 16015-050, Araçatuba, SP, Brasil. Tel: +55-18-3636-3240. Fax: +55-183636-3332. e-mail: poi@foa.unesp.br

Key Words: storage medium, dental avulsion, tooth replantation.

\section{Introduction}

Dentoalveolar trauma affects great part of the Brazilian population (1) and may result in the early loss of teeth, leading to functional, psychological and esthetic problems. Avulsion of permanent teeth is the most serious of all types of traumatic tooth injuries because the complete dislodgement of the tooth from its socket causes severe damage to the supporting tissues and vascular and nerve structures $(2,3)$. It corresponds to $1 \%$ to $16 \%$ of all types of tooth injuries involving the permanent dentition (4-6). This wide variation can be explained by the differences in the evaluated populations, including the levels of interpersonal violence, involvement in motorcycle and bicycle road and traffic accidents, especially without use of helmets, and practice of contact sports, especially without use of mouthguards (7). The 7-10-year-old age group is the most affected by this injury due to the engagement of children of this age in playful and sports practices that 
involve direct body contact $(8-10,11,12)$.

The prognosis of a replanted tooth and its maintenance on the dental arch for the longest possible time depends on the viability of the periodontal ligament (PDL) cells remaining on root surface, integrity of root cementum and minimal bacterial contamination $(13,14)$, which are conditions directly related to the extra-alveolar time, type of storage after avulsion and root surface alterations. The ideal treatment for an avulsed permanent tooth is its immediate replantation into the socket. However, in spite of its recognized therapeutic value, clinical experience has shown that immediate replantation rarely occurs due to factors associated to the accident itself, such as presence of extensive life-threatening injuries, complex damage to the recipient site, patient's emotional condition at the moment of trauma, or simply lack of knowledge or confidence of the general population and even professionals about replantation procedures (14). Victims of maxillofacial traumas involving tooth avulsion usually receive the first aid from non-dental trained personnel. Therefore, in most situations, important factors for the success of replantation cannot be controlled. Studies have shown that this scenario can be improved significantly with educational campaigns on dentoalveloar trauma and storage media directed to common people and non-dental health professionals, especially those working in emergency assistance services $(15,16,17,18)$ to obtain a positive behavioral change to obtain a successful treatment.

Immediate tooth replantation leads to a better PDL repair and reduces significantly the occurrence of root resorption. Therefore, shortening as much as possible the time elapsed between trauma and tooth replantation and maintaining the avulsed tooth in a suitable transport medium may attenuate the deleterious effects of the extrabuccal period on root surface and increase the prognosis considerably $(4,5,6,19,20,21)$. As replantation of avulsed teeth occurs more frequently between 1 and $4 \mathrm{~h}$ after avulsion, degeneration of cemental PDL fibers is a common event and the presence of necrotic PDL remnants on root surface stimulates the occurrence of inflammatory root resorption, which is the major cause of loss of replanted teeth (1).

In this way, short extra-alveolar time, endodontic therapy, administration of systemic antibiotics and adequate handling and maintenance of the tooth up to the moment of replantation are the conditions leading to a better prognosis (22). However, adverse situations may occur, such as ankylosis and different types of root resorption, depending especially on the storage time and the characteristics and temperature of the storage medium. In fact, the capacity of the storage medium to maintain the viability of PDL cells has been considered as more important than the extra-alveolar time $(2,3,23)$. Different types of wet storage media for avulsed teeth have been investigated, which may vary from cell and tissue culture solutions like Hank's Balanced Salt Solution (HBSS); medical/hospital products developed specifically for organ storage purposes, such as Viaspan ${ }^{\circledR}$ and Euro-Collins ${ }^{\circledR}$; culture media, like Minimum Essential Medium (MEM); saline; natural products like water, saliva, bovine milk and its variations, propolis, green tea, Morus rubra (red mulberry), egg white and coconut water; rehydrating solutions, like Gatorade ${ }^{\circledR}$ and Ricetral, and even contact lens solutions.

This paper reviews the literature on the different storage media that have been investigated for avulsed teeth based on full-length papers retrieved from electronic full-text databases considering their characteristics, efficacy and accessibility.

\section{Material and Methods}

Using the key words 'storage media', 'tooth replantation', 'tooth avulsion,' 'milk' and 'propolis', PubMed/Medline, Lilacs, BBO and SciELO electronic databases were searched for research articles, reviews of literature, animal laboratory studies and laboratory studies involving cell counting in human teeth assessing the PDL cell viability after storage of avulsed teeth in different substances, which had been published in English and Portuguese between 2000 and 2011. Papers without an abstract and those that evaluated pulp cell viability and root surface treatment were not included. From a total of 234 papers, 39 articles were selected after application of the inclusion and exclusion criteria, and were critically reviewed for comparison of the outcomes.

\section{Review of Literature}

The search for a single, ideal storage medium that is capable of maintaining PDL and pulp cell viability, while presenting clonogenic capacity, antioxidant property, no or minimal microbial contamination, compatible physiological $\mathrm{pH}$ and osmolality, high availability, ready accessibility and low cost $(2,3,23,24)$, is one of the main interests of dental trauma research.

The main characteristics, efficacy and accessibility of the storage media for avulsed teeth described in this review are summarized in Table 1. A categorization of the storage media according to their efficacy and ease of access are displayed in Table 2.

Hank's Balanced Salt Solution (HBSS) has been especially developed for cell maintenance and thus, theoretically, it allows a better conservation of tissues for long time periods. It has been widely employed as a reference solution in studies on dental avulsion as it has the ideal osmolality and $\mathrm{pH}$ for preserving the vitality of cells $(2,3,7,13,16,23,25-35)$. 
Hwang et al. (16) reported $94 \%$ cell viability after storage of cultured human PDL cells for $24 \mathrm{~h}$ in this medium, which is considered an excellent result, and Souza et al. (36) had similar results to those of the positive control (MEM) by the Tripan blue exclusion method for up to $6 \mathrm{~h}$. Evaluating cell viability using extracted human teeth, Pillegi et al. (30) observed approximately 90\% cell viability. However, its use is restricted to laboratory environments and is not available at an accident site, which makes it impracticable as a storage medium. In addition, HBSS should be used at $37^{\circ} \mathrm{C}$ in a controlled incubator, which may explain the inefficacy of this solution in some studies, if compared with other media $(2,3,36,37)$. The Save-A-Tooth solution, which contains HBSS, showed inferior results than the original product $(34,35)$, which may be explained by the fact that HBSS is prepared for immediate use, when it has a better performance.

MEM cell culture medium contains L-glutamin, penicillin, streptomycin, Nistatin, bovine serum and nutrients for cell growth and proliferation $(25,26)$, and several authors have reported its efficacy in preserving the viability of PDL cells and have indicated it as a storage medium before tooth replantation $(7,26,27,34,35,37)$.

Viaspan ${ }^{\circledR}$ (Belzer VW-CSS; Du Pont Pharmaceuticals, Wilmington, $D E, U S A$ ) is a widely used solution for the storage and transportation of organs to be transplanted. In Dentistry it is used as a storage medium for avulsed teeth because it maintains PDL cell vitality, leading the cases to a better prognosis. Recent studies demonstrated its efficacy in long periods of storage, due to its $320 \mathrm{~m} 0 \mathrm{sm} / \mathrm{kg}$ osmolality and $7.4 \mathrm{pH}$, characteristics that are favorable to cell growth, maintaining the PDL cells viable. Generally, Viaspan ${ }^{\circledR}$ is considered as a medium close to ideal, but the limited access to it, especially at the moment of the accident, makes it difficult to use $(25,26,38)$. The interest for the Euro-Collins solution as a storage medium for avulsed teeth is due to the fact that it is a hypothermal medium developed for preserving organs to be transplanted. Its characteristics include a pH of 7.4, electrolytes and phosphate buffer to control cell acidosis, a high concentration of potassium to decrease the intracellular cation loss, a low concentration of sodium and chlorine, a osmolality of $420 \mathrm{m0sm} / \mathrm{kg}$, maintained by the addition of glucose, which avoids cell edema. Sottovia et al. (38), in a histological and histometric analysis of avulsed dog's teeth stored in the Euro-Collins solution, observed similar results to those observed after immediate replantation, with good repair of supporting tissues, repair and reorganization of vessels and PDL collagen fibers and neoformation of cementum. In general, cell culture solutions and solutions developed to receive organs to be transplanted, have peculiar characteristics that allow maintaining cell viability, minimize damages to PDL cells and provide conditions for cell proliferation, therefore can be indicated for use as storage media for avulsed teeth. The literature has demonstrated their excellent efficacy $(2,3,7,13,16,23,25-38,40)$, but their lack of availability and high cost make their routine use unviable, and thus these solutions are used in very special cases, such as laboratory studies.

Saline has physiological osmolality and $\mathrm{pH}$, but it does not contain essential ions and glucose, which are fundamental for the cells $(13,25,26)$ and for this reason has been suggested as an interim storage medium for up to $4 \mathrm{~h}(22,28-30)$. Moreira-Neto et al. (22) evaluated the viability of cultured cells and found 55\% of living cells after $4 \mathrm{~h}$ storage and Pileggi et al. (25) evaluated the PDL cells viability when maintained in this medium for 45 min and resulted in only 20\% mortality. Using a similar methodology, Martin and Pileggi (28) found that saline had a worse behavior compared with HBSS and milk. Evaluating cell viability by the Tripan blue method, Ozan et al. (29) concluded that water was worse than saline. Consequently, saline is not an adequate medium, but it may be employed for short periods of time.

Tap water has inadequate characteristics to be used as a storage medium for avulsed teeth because it has bacterial contamination, hypotonicity, and non-physiological pH and osmolality, which favors the PDL cells lysis $(25,26,39)$. Several studies have shown that cells stored in water did not maintain their morphology, with visible destruction and rapid cell death $(16,23,34,35)$. In view of this, tap water should be used only to avoid tooth dehydration, but it is inadequate for conservation of avulsed teeth.

Similar to water, human saliva (buccal vestibule) is used as a storage medium due to its availability, but it has unfavorable characteristics, such as non-physiological $\mathrm{pH}$ and osmolality, high microbial contamination and hypotonicity $(25,26,32,41)$. Studies have shown that saliva is inefficient to maintain cell viability $(30,34)$, but it is preferable to use it rather than keep the tooth in dry conditions because the effects of resorption become more severe with time (7). There is evidence that artificial saliva is also inappropriate to receive avulsed teeth. Sousa et al. (41) found disorganization of collagen fibers, altering therefore the PDL quality. In view of the studies that used both the human and artificial saliva, they cannot be considered as adequate media.

Water and saliva are similar and cause a rapid lysis of the cell membrane, have $\mathrm{pH}$ and osmolality incompatible to the cells, in addition to being contaminated media, particularly saliva, because the oral cavity hosts a wide resident and transient microbiota. Studies using these media for storage of avulsed teeth ultimately show a very poor efficacy and they were frequently used as negative 
controls $(7,16,23,25,26,32,34,35,39,41)$. Saline has only physiological pH and osmolality, but such characteristics are insufficient to maintain good cell viability $(13,22,25,28)$. Water and saliva can be found everywhere and saline may be easily encountered in a variety of places; with this wide availability, it is more convenient to use them for short periods than let the tooth dry out.

Milk has several favorable characteristics as a storage medium for avulsed teeth, as it is an isotonic liquid with an approximately neutral $\mathrm{pH}$ and physiological osmolality, has

Table 1. Main characteristics, efficacy and accessibility of each storage medium for avulsed teeth

\begin{tabular}{|c|c|c|c|}
\hline Storage medium & Characteristics & Efficacy & Accessibility \\
\hline $\begin{array}{l}\text { Hank’s Balanced Salt } \\
\text { Solution (HBSS) }\end{array}$ & Physiological pH, osmolality and nutrients & Excellent & - - \\
\hline Viaspan ${ }^{\circledR}$ & Physiological pH, osmolality and favorable to cell growth & Excellent & -- \\
\hline Euro-Collins ${ }^{\circledR}$ & Physiological pH and hypothermal capacity & Excellent & -- \\
\hline $\begin{array}{l}\text { Minimum Essential } \\
\text { Medium (MEM) }\end{array}$ & Nutrients, antimicrobial property and growth factors & Excellent & - - \\
\hline Saline & Physiological pH and osmolality & Poor & + \\
\hline Water & $\begin{array}{l}\text { Microbial contamination, hypotonic, non- } \\
\text { physiological pH and osmolality }\end{array}$ & Very poor & ++ \\
\hline Saliva & $\begin{array}{l}\text { Microbial contamination, hypotonic, non- } \\
\text { physiological pH and osmolality }\end{array}$ & Very poor & ++ \\
\hline Milk & $\begin{array}{l}\text { Small bacterial contents, isotonic, physiological } \\
\mathrm{pH} \text {, osmolality, growth factors and nutrients }\end{array}$ & Excellent & + \\
\hline Propolis & Antiinflammatory, antibacterial and antioxidant properties & Excellent & - \\
\hline Green tea & Antiinflammatory, antibacterial and antioxidant properties & Excellent & - \\
\hline Red mulberry & Not established & Good & - \\
\hline Egg white & $\begin{array}{l}\text { Low microbial contamination, } \\
\text { contains nutrients and water }\end{array}$ & Good & + \\
\hline Coconut water & Sterile, natural product and contains nutrients & Good & + \\
\hline Gatorade & Low $\mathrm{pH}$ and hypertonic & Poor & + \\
\hline Ricetral & Essential cells and nutrients & Good & + \\
\hline Contact lens solution & Antimicrobial property, preservatives & Poor & + \\
\hline
\end{tabular}


low or no bacterial content, contains growth factors and essential nutrients for cells, in addition to having a high availability mostly everywhere and low cost $(25,26)$. Being a gland secretion, milk contains epithelial growth factor (EGF), which stimulates the proliferation and regeneration of epithelial cell rests of Malassez and activates the alveolar bone resorption. This will ultimately contribute to isolate the bone tissue from the tooth and decrease the likelihood of ankylosis (42). In spite of offering no conditions for the restoration of cell morphology nor cell differentiation or mitosis, milk prevents cell death $(7,13,22,24-26,30,33-$

Table 2. Categorization of the storage media according to their efficacy and ease of access

\begin{tabular}{|c|c|c|}
\hline Efficacy & Ease of access & Storage medium \\
\hline Excellent & ++ & --- \\
\hline Excellent & + & Milk \\
\hline Excellent & - & Propolis, Green tea \\
\hline Excellent & - - & $\begin{array}{c}\text { HBSS, MEM, Viaspan }{ }^{\circledR}, \\
\text { Euro-Collins }{ }^{\circledR}\end{array}$ \\
\hline Good & ++ & --- \\
\hline Good & + & $\begin{array}{l}\text { Coconut water, } \\
\text { Egg, Ricetral }\end{array}$ \\
\hline Good & - & Red mulberry \\
\hline Good & - & --- \\
\hline Poor & ++ & --- \\
\hline Poor & + & $\begin{array}{l}\text { Saline, Gatorade } \\
\text { Contact lens solution }\end{array}$ \\
\hline Poor & - & --- \\
\hline Poor & -- & --- \\
\hline Very poor & ++ & Water, saliva \\
\hline Very poor & + & --- \\
\hline Very poor & - & --- \\
\hline Very poor & - - & --- \\
\hline
\end{tabular}

$36,41,43)$. Several authors that evaluated the viability of PDL cells in contact with milk have reported 70 to $90 \%$ survival rates and low frequency of root resorptions after periods up to $72 \mathrm{~h}(7,13,22,24,30,33,34-36,43,44)$. Regarding the different milk presentations, Marino et al. (27) reported that there was no significant difference between regular pasteurized milk and long shelf-life ultra high temperature (UTH) pasteurized whole milk at any time period. Pearson et al. (39) evaluated the efficacy of several milk substitutes, including reconstituted powdered milk, evaporated milk and two baby formulas (Similac and Enfamil) compared with regular pasteurized whole milk and reported that Enfamil, which is supplied in powder form, does not require special storage and has a shelf life of 18 months, is a more effective storage medium for avulsed teeth than the pasteurized whole milk for at least $4 \mathrm{~h}$. Some authors reported superior results with the green tea, Eurocollins ${ }^{\circledR}$, coconut water, propolis, egg and Ricetral media $(2,3,16,18,28,37,38,43)$ in relation to milk. In spite of this, milk has been widely recommended to dentists and general population for keeping avulsed teeth to be replanted, being the second or third best transportation media for avulsed teeth include (in order of preference), after Viaspan ${ }^{\circledR}$ and/or Hank's Balanced Salt Solution ${ }^{\circledR}$, according to the International Association of Dental Traumatology (45), and the American Academy of Pediatric Dentistry (46) due to its beneficial effects and characteristics, and its ease of access at the moment of trauma.

Propolis is a natural substance produced by honeybees with remarkable antioxidant, antiinflammatory and antimicrobial properties. It has been studied in Dentistry for caries prevention, as an intracanal medication in endodontic treatment, and as a storage medium for avulsed teeth. Casaroto et al. (7) reported good results for maintenance of cell viability, but the root resorptions were visible, which compromises its efficacy for this purpose. On the other hand, Gopikrishna et al. (2) found that propolis had $50 \%$ efficacy in maintaining cell viability, while Martin and Pileggi (28) considered propolis as the most efficient medium. Such variation of results may be explained by the complex chemical composition of propolis, which varies according to the location of plants, climate and even the seasons that define the different quantities of volatile oils, waxes, resins, balms, pollen, vitamins and sugars $(2,3,7,25,26,28)$. The storage time is also an important factor to be considered. Mori et al. (24) investigated the ideal period for maintaining the tooth in propolis and concluded that the efficacy of the medium increases if maintained for $6 \mathrm{~h}$ because the contact with product is beneficial for cell maintenance. Another variable that could produce contradicting results is the propolis dilution vehicle. The most frequently used vehicle is ethanol $(2,7,28)$, 
but the Dulbecco's modified Eagle's medium (DMEM) culture medium has also been used (37). Depending on the methodology, ethanol could have had any interference on the results, but propolis has the capacity to neutralize the toxic effects of ethanol, at least in part. This makes propolis a promising medium for the maintenance of avulsed teeth, stimulating further research to improve its applicability and widen its indication of use.

Some studies have proven that the green tea extract has strong antioxidant, antiinflammatory and antibacterial properties, good anticarcinogenic effect (16), good ability to extend the survival of grafts and capacity to protect the periodontal tissues against the resorption of alveolar bone as a result of infectious processes caused by pathogenic microorganisms (47). Additionally, Hwang et al. (16) and Jung et al. (47) in the search for a medium capable of minimizing the infections after tooth replantation, maintaining PDL cell viability and reducing root resorption and ankylosis, reported enthusiastic results with green tea, with the maintaince of $90 \%$ of cell viability for up to $24 \mathrm{~h}$, similar to the HBSS control. Jung et al. (47) also observed that the higher the extract concentration the more efficient the medium. In view of this, the use of green tea extract and its compounds may be an alternative for the conservation of avulsed teeth and its beneficial effect is enhanced by higher extract concentrations.

Morus rubra (red mulberry) is a natural product available in different climates, which contains flavonoids, alkaloids and polysaccharides, all of them very important for cell preservation. Ozan et al. (29) reported that when teeth were stored in red mulberry for up to $12 \mathrm{~h}$, its capacity to maintain the viability of PDL cells was better than that of HBSS; however, if a longer storage time is required, it is advisable to employ higher concentrations of the fruit juice. There are very few studies evaluating the use of red mulberry juice as a transport medium for avulsed teeth and its biological proprieties have not been yet established yet. Further research is necessary before its use can be recommended $(26,29)$.

The antibacterial and antiinflammatory actions of green tea and propolis demonstrate their capacity to inhibit prostaglandin synthesis, aiding the immune system in the phagocytic activity and promoting healing effects in the epithelial tissue $(2,3,7,16,24,28,47)$. Additionally, one or more antioxidant composites in these substances may increase the success rate of tooth replantation because they prevent the harmful effects of the free radicals, modulating the osteoblast and osteoclast activity $(26,29)$. Propolis also contains iron and zinc, important for collagen synthesis, and bioflavonoids that help in the contention of hemorrhages of the PDL tissue and stimulate the stimulate enzymes that fortify the walls of the blood vessels in the periodontium (7).
The red mulberry characteristics are not yet well described in the literature, but this fruit seems to contain great amount of flavonoids, alkaloids and polysaccharides in addition to antioxidant substances $(26,29)$. Even though these natural products present promising results as media for avulsed teeth, their lack of availability limit their indication and require some preparation for use like tea, juice or a more elaborate laboratory preparation for propolis.

Egg white and ovalbumin, the major protein in egg white, are considered a good choice as a storage media for teeth undergoing delayed replantation due to its high content of proteins, vitamins and water, absence of microbial contamination and easy access $(25,26)$. Sousa et al. (41) evaluating human PDL adhered to extracted tooth roots and maintained in this storage medium observed that the egg white provided cell viability and histological characteristics similar to those of milk. Khademi et al. (48) compared milk and egg white as solutions for storing avulsed teeth, and found that teeth stored in egg white for 6 to $10 \mathrm{~h}$ had a better incidence of repair and lower surface resorption than those stored in milk for the same amount of time and index than the controls. The great amount of proteins, vitamins and water may lead to positive or negative results in relation to the efficacy of egg white and its protein as storage medium for avulsed teeth $(25,26,41,48)$. Some experiments indicate that this is a very good medium to maintain cell viability, but others show a small loss of efficacy overtime, possibly due to egg's high $\mathrm{pH}$ and also because the PDL cells could target the several egg proteins as strange bodies. Further studies are required to confirm theses adverse effects, as there are wide variations in egg composition and quality.

Coconut water is a natural, biologically pure, sterile product rich in amino acids, proteins, vitamins and minerals. Several studies have been performed to use this substance as a storage medium for avulsed teeth, but the results are contradictory. Gopikrishna et al. (2) and Gopikrishna et al. (3) found greater efficacy of coconut water over HBSS and milk for the viability of PDL. Thomas et al. (23) found that 15 to $120 \mathrm{~min}$ storage in coconut water is as efficient as storage in HBBS. On the other hand, Pearson et al. (39) and Thomas et al. (23) observed that inflammatory resorption was more frequent when the tooth was maintained in coconut water compared with milk. Moreira-Neto et al. (22) and Souza et al. (36) also reported that milk presented a better performance than coconut water in relation to the cell viability. It is therefore difficult to consider coconut water as an adequate storage medium for avulsed teeth. Standardized studies with similar methods are required to avoid diverging results and eliminate doubts over its use, as this is a medium with easy access and good biological characteristics that 
could be promising for its indication.

Gatorade ${ }^{\circledR}$ is a sports drinks used for rehydration. This substance has $\mathrm{pH} 3$ and osmolality between 280 and 360 mOsm, which may cause damage to the cells due to the low pH and hypertonicity (25). Sigalas et al. (33) evaluated Gatorade efficacy in maintaining the viability of PDL cell culture by the Tripan blue exclusion method and the results showed that at $37^{\circ} \mathrm{C}$ it was toxic to the cells; but this may be an alternate medium to HBSS and milk when used ice cold and for a short time.

Dehydration, as in diarrhea cases, is treated with oral rehydration solutions like Ricetral, which contains essential cells and nutrients like glucose and vital salts in concentrations considered adequate for the cell metabolism. These solutions are available in drugstores at low cost and their components are able to maintain the body hydrated by reposition of liquids lost in the intestine. Rajendran et al. (31) evaluated the PDL cell viability of extracted human teeth by the Tripan blue exclusion method and the results showed that Ricetral was similar to the HBSS control and both were superior to milk.

The number of people using contact lenses is growing and consequently there is also great availability of solutions for cleaning contact lenses in homes, schools and centers of physical activities $(25,33)$. These solutions are fatty acid monoester composites with an antimicrobial cationic component. Sigalas et al. (33) studied the efficacy of different contact lens solutions in maintaining the viability of cultured PDL cells by the Tripan blue exclusion method and the results showed that the preservatives in the formula damaged the cells. Nonetheless, in the absence of another storage medium, they may be used instead of water or saline for short periods of time.

Coconut water, Gatorade ${ }^{\circledR}$, Ricetral and contact lens solutions were tested as storage media for avulsed teeth as a form of maintaining the hydration of the cells, which is favorable for an occasional use. Coconut water composition is quite similar to that of the intracellular fluid, which is a positive factor in the nutrition and vitality of the cells $(2,3,22,23,39)$. Gatorade ${ }^{\circledR}$ and contact lens solutions do not present quite positive results, probably because their characteristics are not very favorable to the cells; however, they may replace water and saliva if required $(25,33)$. Ricetral may also retain some cell viability and provide conditions for the maintenance of cell metabolism (31).

\section{Final Considerations}

Up to now, there is not a single product or solution that possesses all the characteristics required to be indicated as the ideal storage medium for avulsed teeth, that is, be capable of preserving the vitality of the PDL and pulp cells, while presenting compatible physiological $\mathrm{pH}$ and osmolality, clonogenic capacity, antioxidant property, no or minimal microbial contamination, high availability, ready accessibility at accident sites, homes, schools, hospitals and dental offices, and low cost. Based on the literature, it could be stated that, so far, apart from solutions designed specifically for storage and culture purposes, regular pasteurized whole milk is the most frequently recommended and with the best prognosis among other solutions that are likely to be available at the scene of an accident, such as water, saline or saliva. Milk is an isotonic liquid with a physiologically compatible $\mathrm{pH}$ and osmolality (fluid pressure) with the root-surface adhered PDL cells, has low or no bacterial content, contains growth factors and essential nutrients for cells, in addition to being highly available mostly everywhere and having a low cost. Taking together the characteristics, efficacy and availability and accessibility, milk appears as the best indication of a temporary storage medium for avulsed teeth before replantation, and its use is recommended by the International Association of Dental Traumatology and the American Academy of Pediatric Dentistry.

\section{Resumo}

Dentre os traumatismos dento-alveolares, a avulsão dentária é a mais severa por causar danos em muitas estruturas e por consistir num deslocamento total do dente de seu alvéolo ósseo. 0 tratamento ideal é o reimplante dentário imediatamente após avulsão, pois o tempo extra-bucal é fator determinante para um bom prognóstico e o sucesso do tratamento. Infelizmente, isto nem sempre é possivel. 0 sucesso do reimplante depende de muitos fatores que podem acelerar ou retardar a reabsorção radicular ou mesmo a anquilose e entre eles estão o tipo e as características do meio de armazenamento no qual esse dente foi mantido entre a avulsão e o reimplante. Manter o dente num meio úmido adequado que possa preservar pelo maior tempo possivel a vitalidade das células do ligamento periodontal na superfície radicular é o elemento-chave do reimplante bem sucedido. Pesquisas recentes levaram ao desenvolvimento de meios de armazenamento que tem condições muito próximas às do alvéolo dental, possuindo osmolalidade (pressão celular) adequada, pH, metabólitos nutrientes e glicose. Embora estes meios de armazenamento possam ser adquiridos comercialmente, a situação mais comum é que o produto não esteja facilmente acessivel no momento do acidente. Frente a isto, o objetivo deste artigo é apresentar uma revisão da literatura sobre diversos meios de armazenamento para dentes avulsionados, considerando suas caracteristicas, efetividade e acessibilidade. Para isto, foi realizada uma busca de artigos nas bases de dados PubMed/Medline, Lilacs, BBO e Scielo por meio das palavras-chave: 'storage media', 'tooth replantation', 'tooth avulsion', 'milk' e 'propolis'. Após a avaliação dentro dos critérios de inclusão e exclusão, 39 artigos foram selecionados e os meios de armazenamento neles descritos foram criteriosamente estudados quanto às suas caracteristicas, efetividade e acessibilidade. A revisão da literatura revelou uma grande variedade de meios úmidos de estocagem avaliada em estudos laboratoriais e casos clínicos, incluindo soluções para cultura de células e tecidos, como a Hank's Balanced Salt Solution (HBSS); produtos médico-hospitalares desenvolvidos especificamente para armazenamento de órgãos, como Viaspan $^{\circledR}$ e Euro-Collins ${ }^{\circledR}$; meios de cultura como o Meio Mínimo Essencial (MEM); solução fisiológica; produtos naturais, como água, saliva, leite bovino em suas diferentes apresentações, própolis, chá verde, Morus rubra, clara de ovo e água de coco; produtos reidratantes como Gatorade ${ }^{\circledR}$ e Ricetral, até mesmo soluções para lentes de contato. Com 
base na literatura, pode-se afirmar que até agora, com exceção das soluções especificas para armazenamento e culturas, o leite pasteurizado integral é o mais indicado e o que tem o melhor prognóstico dentre as substâncias que estejam mais provavelmente disponiveis no local do acidente, como água, solução fisiológica ou saliva. Suas vantagens são a grande disponibilidade, fácil acesso, $\mathrm{pH}$ fisiologicamente compatível e osmolalidade (pressão do líquido) com as células do ligamento periodontal aderidas à superfície radicular, presença de nutrientes e fatores de crescimento. Apesar disso, o fato é que não se tem um produto que preencha todos os requisitos para ser considerado ideal para o armazenamento temporário de dentes avulsionados e as pesquisas para tanto devem prosseguir.

\section{References}

1. Andreasen JO. Effect of extra-alveolar period and storage media upon periodontal and pulp healing after replantation of mature permanent incisors in monkeys. Int J Oral Surg 1981;1043-1053.

2. Gopikrishna V, Baweja PS, Venkateshbabu N, Thomas T, Kandaswamy D. Comparison of coconut water, propolis, HBSS, and milk on PDL cell survival. J Endod 2008;34:587-589.

3. Gopikrishna $V$, Thomas T, Kandaswamy D. A quantitative analysis of coconut water: a new storage media for avulsed teeth. Oral Surg Oral Med Oral Pathol Oral Radiol Endod 2008;105:61-65.

4. Andreasen J, Andreasen F. Textbook and color atlas of traumatic injuries to the teeth, 3rd ed. Copenhagen: Munksgaard;1994. p. 383-425.

5. Petersson EE, Andersson L, Sorensen S. Traumatic oral vs non-oral injuries. Swed Dent J 1997;21:55-68.

6. Panzarini SR, Gulinelli JL, Poi WR, Sonoda CK, Pedrini D, Brandini DA. Treatment of root surface in delayed tooth replantation: a review of literature. Dent Traumatol 2008; 24:277-282.

7. Casaroto AR, Hidalgo MM, Sell AM, Franco SL, Cuman RKN, Moreschi E, et al.. Study of the effectiveness of propolis extract as a storage medium for avulsed teeth. Dent Traumatol 2010;26:323-331.

8. Andreasen JO, Andreasen FM, Andersson L. Textbook and color atlas of traumatic injuries to the teeth, 4th edn. Oxford: Blackwell Munksgaard; 2007.

9. Andreasen JO, Borum MK, Andreasen FM. Replantation of 400 avulsed permanent incisors. Factors related to root growth. Endod Dent Traumatol 1995; 11:69-75.

10. Andreasen JO, Borum MK, Jacobsen HL, Andreasen FM. Replantation of 400 avulsed permanent incisors. Diagnosis of healing complications. Endod Dent Traumatol 1995; 11:51-58.

11. Flores MT, Aandersson L, Andreasen JO, Bakland LK, Malmgren $B$, Barnett $F$, et al.. Guidelines for the management of traumatic dental injuries. II. Avulsion of permanent teeth. Dent Traumatol 2007;23:130-136.

12. Soares A de J, Gomes BP, Zaia AA, Ferraz CC, de Souza-Filho FJ. Relationship between clinical-radiographic evaluation and outcome of teeth replantation. Dent Traumatol 2008;24:183-188.

13. Çaglar E, Sandalli N, Kuscu 00, Durhan MA, Pisiriciler R, Calıskan EA, et al.. Viability of fibroblasts in a novel probiotic storage media. Dent Traumatol 2010;26:383-387.

14. Cardos LC, Poi WR, Panzarini SR, Sonoda CK, Rodrigues TS, Manfrin TM. Knowledge of firefighters with special paramedic training of the emergency management of avulsed teeth. Dent Traumatol 2009;25:58-63.

15. Perri de Carvalho AC. Immediate tooth replantation: report of educational campaign. Rev Assoc Paul Cirurg Dent 1988;42:248249.

16. Hwang JY, Choi SC, Park JH, Kang SW. The use of green tea extract as a storage medium for the avulsed tooth. Basic research. Biology 2011;37:962-967.

17. Poi WR, Salineiro SL, Miziara FV, Miziara EV. Education as a means of enhancing the prognosis of tooth replantation. Rev Assoc Paul Cir Dent 1999;53:474-479.

18. Sae-Lim V, Lim LP. Dental trauma management awareness of Singapore pre-school teachers. Dent Traumatol 2001;17:71-76.
19. Pohl Y, Fillippi A, Kirschner H. Results after replantation of avulsed permanent teeth. II. Periodontal healing and the role of physiologic storage and antiresorptive-regenerative therapy. Dent Traumatol 2005;21:93-101.

20. Schwartz 0, Andreasen FM, Andreasen JO. Effects of temperature, storage time and media on periodontal and pulpal healing after replantation of incisors in monkeys. Dent Traumatol 2002;18:190195.

21. Panzarini SR, Gulinelli JL, Poi WR, Sonoda CK, Pedrini D, Brandini DA. Treatment of root surface in delayed tooth replantation: a review of literature. Dent Traumatol 2008; 24:277-282.

22. Moreira-Neto JJS, Gondim JO, Raddi MSG, Pansani CA. Viability of human fibroblasts in coconut water as storage medium. Intern Endod J 2009;42:827-830.

23. Thomas T, Gopikrishna V, Kandaswamy D. Comparative evaluation of maintenance of cell viability of an experimental transport media "coconut water" with Hank's balanced salt solution and milk, for transportation of an avulsed tooth: an in vitro cell culture study. J Conserv Dent 2008;11:22-29.

24. Mori GG, Nunes DC, Castilho LR, Moraes IG, Poi WR. Propolis as storage media for avulsed teeth: microscopic and morphometric analysis in rats. Dent Traumatol 2010;26:80-85

25. Goswami M, Chaitra TR, Chaudhary S, Manuja N, Sinha A. Strategies for periodontal ligament cell viability: an overview. J Conserv Dent $2011 ; 14: 215-220$

26. Malhotra N. Current developments in interim transport (storage) media in dentistry: an update. Br Dent J 2011;211:29-33.

27. Marino T, West LA, Liewehr FR, Mailhot JM, Buxton TB, Runner RR, et al.. Determination of periodontal ligament cell viability in long shelf-life milk. J Endod 2000;26:699-702.

28. Martin MP, Pileggi R. A quantitative analysis of propolis: a promising new storage media following avulsion. Dent Traumatol 2004;20:8589.

29. Özan F, Tepe B, Polat ZA, Er K. Evaluation of in vitro effect of Morus rubra (red mulberry) on survival of periodontal ligament cells. Oral Surg Oral Med Oral Pathol Oral Radiol Endod 2008;105:e66-69.

30. Pileggi R, Dumsha TC, Nor JE. Assessment of post-traumatic PDL cells viability by a novel collagenase assay. Dent Traumatol 2002;18:186189.

31. Rajendran P, Varghese NO, Varughese JM, Murugaian E. Evaluation, using extracted human teeth, of Ricetral as a storage medium for avulsions - an in vitro study. Dent Traumatol 2011;27:217-220.

32. Schwartz 0, Andreasen FM, Andreasen J0. Effects of temperature, storage time and media on periodontal and pulpal healing after replantation of incisors in monkeys. Dent Traumatol 2002;18:190195.

33. Sigalas E, Regan JD, Kramer PR, Witherspoon DE, Opperman LA. Survival of human periodontal ligament cells in media proposed for transport of avulsed teeth. Dent Traumatol 2004;20:21-28.

34. Souza BDM, Bortoluzzi EA, Teixeira CS, Felippe WT, Simões CMO, Felippe MCS. Effect of HBSS storage time on human periodontal ligament fibroblast viability. Dent Traumatol 2010;26:481-483.

35. Souza BDM, Luckemeyer DD, Felippe WT, Simões CMO, Felippe MCS. Effect of temperature and storage media on human periodontal ligament fibroblast viability. Dent Traumatol 2010;26:271-275.

36. Souza BDM, Luckemeyer DD, Reyes-Carmona JF, Felippe WT, Simões CMO, Felippe MCS. Viability of human periodontal ligament fibroblasts in milk, Hank's balanced salt solution and coconut water as storage media. Int Endod J 2011;44:111-115.

37. Özan F, Polat ZA, Er K, Özan Ü, Deger O. Effect of propolis on survival of periodontal ligament cells: new storage media for avulsed teeth. J Endod 2007;33:570-573.

38. Sottovia AD, Sottovia Filho D, Poi WR, Panzarini SR, Luize DS, Sonoda CK. Tooth replantation after use of euro-collins solution or bovine milk as storage medium: a histomorphometric analysis in dogs. J Oral Maxillofac Surg 2010;68:111-119.

39. Pearson RM, Liewehr FR, West LA, Patton WR, McPherson JC, Runner RR. Human periodontal ligament cell viability in milk and milk substitutes. J Endod 2003;29:184-186. 
40. Trope M, Friedman S. Periodontal healing of replanted dog teeth stored in Viaspan, milk and Hank's balanced salt solution. Endod Dent 1992;8:183-188.

41. Sousa HA, Alencar HG, Bruno KF, Batista AC, Carvalho ACP. Microscopic evaluation of the effect of different storage media on the periodontal ligament of surgically extracted human teeth. Dent Traumatol 2008;24:628-632.

42. Consolaro, A. Dental resorptions in clinical specialties. 2ed. Maringá: Dental Press. 2005.

43. Santos CLV, Sonoda CK, Poi WR, Panzarini SR, Sundefeld MLMM, Negri MR. Delayed replantation of rat teeth after use of reconstituted powdered milk as a storage medium. Dent Traumatol 2009;25:51-57.

44. Blomlöf L, Lindskog S, Hammarström L. Periodontal healing of exarticulated monkey teeth stored in milk or saliva. Scand J Dent Res 1981;89:251-259.
45. Flores MT, Andersson L, Andreasen JO, Bakland LK, Malmgren B, Barnett F, et al.. International Association of Dental Traumatology. Guidelines for the management of traumatic dental injuries. II. Avulsion of permanent teeth. Dent Traumatol 2007;23:130-136.

46. American Academy of Pediatric Dentistry (http://www.aapd.org/ media/Policies_Guidelines/G_trauma.pdf)

47. Jung IH, Yun JH, Cho AR, Kim CS, Chung WG, Choi SH. Effect of (-)-epigallocatechin-3-gallate on maintaining the periodontal ligament cell viability of avulsed teeth: a preliminary study. J Periodontal Implant Sci 2011;41:10-16.

48. Khademi AA, Atbaee A, Razavi SM, Shabanian M. Periodontal healing of replanted dog teeth stored in milk and egg albumen. Dent Traumatol 2008;24:510-514.
Received October 10, 2013 Accepted December 1, 2013 